Review

\title{
Systematic studies on ciliates (Alveolata, Ciliophora) in China: Progress and achievements based on molecular information
}

\author{
Feng Gao ${ }^{\mathrm{a}, 1}$, Jie Huang ${ }^{\mathrm{a}, \mathrm{b}, 1}$, Yan Zhao ${ }^{\mathrm{a}, \mathrm{c}, 1}$, Lifang Li ${ }^{\mathrm{a}, \mathrm{d}, 1}$, Weiwei Liu ${ }^{\mathrm{a}, \mathrm{e}, 1}$, \\ Miao Miao ${ }^{\mathrm{a}, \mathrm{f}, 1}$, Qianqian Zhang ${ }^{\mathrm{a}, \mathrm{g}, 1}$, Jiamei Li ${ }^{\mathrm{a}, 1}$, Zhenzhen Yi ${ }^{\mathrm{a}, \mathrm{h}, *}$, \\ Hamed A. El-Serehy ${ }^{\mathrm{i}}$, Alan Warren ${ }^{\mathrm{j}}$, Weibo Song ${ }^{\mathrm{a}, \mathrm{k}}$
}

\author{
anstitute of Evolution and Marine Biodiversity, Ocean University of China, Qingdao 266003, China \\ ${ }^{\mathrm{b}}$ Key Laboratory of Aquatic Biodiversity and Conservation, Institute of Hydrobiology, Chinese Academy of Sciences, Wuhan 430072, China \\ ${ }^{\mathrm{c}}$ Research Center for Eco-Environmental Sciences, Chinese Academy of Sciences, Beijing 100085, China \\ ${ }^{\mathrm{d}}$ Marine College, Shandong University, Weihai 264209, China \\ ${ }^{\mathrm{e}}$ Key Laboratory of Tropical Marine Bio-resources and Ecology, South China Sea Institute of Oceanology, Chinese Academy of Science, \\ Guangzhou 510301, China \\ ${ }^{\mathrm{f}}$ College of Life Sciences, University of Chinese Academy of Sciences, Beijing 100049, China \\ ${ }^{\mathrm{g}}$ Yantai Institute of Coastal Zone Research, Chinese Academy of Sciences, Yantai 264003, China \\ ${ }^{\mathrm{h}}$ Guangzhou Key Laboratory of Subtropical Biodiversity and Biomonitoring, South China Normal University, Guangzhou 510631, China \\ ${ }^{i}$ Department of Zoology, King Saud University, Riyadh 11451, Saudi Arabia \\ ${ }^{j}$ Department of Life Sciences, Natural History Museum, London SW7 5BD, UK \\ ${ }^{\mathrm{k}}$ Laboratory for Marine Biology and Biotechnology, Qingdao National Laboratory for Marine Science and Technology, Qingdao 266003, \\ China
}

Available online 6 May 2017

\begin{abstract}
Due to complex morphological and convergent morphogenetic characters, the systematics of ciliates has long been ambiguous. Since 1990, the Laboratory of Protozoology, Ocean University of China, in collaboration with other research groups worldwide, has carried out a series of integrative investigations on ciliate systematics. To date, genomic DNA has been extracted from about 1700 ciliate strains, and phylogenetic analyses have been performed for two-thirds of orders. Main findings are: (1) Classifications of about 50 hypotrichous species have been resolved, although the monophylies of three hypotrichous orders remain unconfirmed; (2) Euplotia and two orders and all seven families within them are monophyletic assemblages; (3) Lynnella represents an order-level taxon, and is separated from two sister monophyletic subclasses Oligotrichia and Choreotrichia; (4) the peritrich families Zoothamniidae and Vorticellidae are separated from each other, and Zoothamnium exhibits a high genetic diversity; (5) the scuticociliate order Philasterida is monophyletic and separated from loxocephalids, and the thigmotrichids is a suborder within Pleuronematida; (6) 14 classes were recovered including one new class Protocruziea, and Mesodiniea is basal to subphyla Intramacronucleata and Postciliodesmatophora; (7) mitochondrial cytochrome $c$ oxidase subunit I heteroplasmy was reported in ciliates for the first time, and candidate barcoding genes for Frontonia species identification were identified.
\end{abstract}

(C) 2017 Elsevier GmbH. All rights reserved.

Keywords: Ciliates; Molecular systematics; Phylogeny; Barcoding

\footnotetext{
${ }^{*}$ Corresponding author at: Guangzhou Key Laboratory of Subtropical Biodiversity and Biomonitoring, South China Normal University.

E-mail address: zyi@scnu.edu.cn (Z. Yi).

${ }^{1}$ These authors contributed equally to this work.
} 


\section{Introduction}

Ciliated protists (ciliates) are a diverse clade of microbial eukaryotes that are the most morphologically complex and highly differentiated taxa among single-celled organisms. They exhibit a combination of unique characters, such as nuclear dimorphism (the presence of a somatic macronucleus and a germline micronucleus), sexual reproduction by conjugation, highly specialized organelles and complex cytoskeletal structures, that make them important model organisms in studies of cell biology, molecular biology, genetics, ecology, and evolution (Hausmann and Bradbury 1996). Traditionally, the taxonomy and systematics of ciliates were mainly based on morphogenetic and morphological characteristics, e.g. ciliature, mouth structure, nuclear apparatus and ultrastructure (Corliss 1979). Over the last three decades, phylogenetic analyses based on molecular data have become increasingly important in determining evolutionary relationships among ciliates (Chen et al. 2015, 2016; Gentekaki et al. 2014; Luo et al. 2015; Wang et al. 2015; Zhang et al. 2014). Considering their high species diversity, however, molecular phylogenetic studies have been performed on only a small proportion of ciliates. This is mainly due to the initial technical difficulties of obtaining and extracting DNA, a problem that has largely been overcome, and a lack of accurate, verifiable morphological and biogeographical data upon which to build molecular studies. Therefore, phylogenetic relationships among many ciliate groups remain unknown, even those which are morphologically and/or morphogenetically well characterized (Xu et al. 2015; Yan et al. 2015, 2016a, 2016b; Zhao et al. 2014).

Since 1990, the research group of the Laboratory of Protozoology in the Institute of Evolution and Marine Biodiversity, Ocean University of China, has carried out a series of investigations on the ciliate fauna in the temperate-tropical seas in China. These studies are supported by a variety of programmes and funding organizations, both national and international, including: the "National Basic Research Program of China (973 Program)", the "Cheung Kong Scholars Programme", the National Natural Science Foundation of China, Deutscher Akademischer Austausch Dienst (Germany), the Royal Society (UK), the Darwin Initiative (UK) and the Center of Excellence in Biodiversity Research (Saudi Arabia). Much of this work has been carried in collaboration with institutions overseas, in particular the University of Bonn, Germany, the Natural History Museum, UK, and the King Saud University, Saudi Arabia. More than 800 morphospecies have been isolated and identified (Song et al. 2003, 2009). Following detailed and accurate taxonomic identification, genomic DNA has been extracted from more than 1700 ciliate species/strains and marker genes have been sequenced e.g. small subunit ribosomal RNA (SSU rRNA) gene (Table 1). Phylogenetic analyses based mainly on gene sequence data have been integrated with the study of morphological and morphogenetic characters for several major ciliate groups including hypotrichs, euplotids, scuticociliates, oligotrichs, peritrichs, heterotrichs etc., covering about twothirds of ciliate orders (Gao et al. 2012; Huang et al. 2012, 2016; Zhang et al. 2012). Additionally, theoretical research focusing on gene marker selection and topological optimization have also been performed in order to provide guidance for future studies (Yi et al. 2010, 2014). The present paper summarizes the main findings of phylogenetic studies performed by our group on five major ciliate lineages, namely hypotrichs, euplotids, oligotrichs, peritrichs and scuticociliates.

\section{Phylogenetic Studies of Hypotrichia}

The subclass Hypotrichia sensu str. is a diverse and cosmopolitan assemblage of ciliates. To date, about 600 valid species have been reported (Berger 1999, 2006, 2008, 2011). The phylogeny of hypotrichs is one of the most frequently discussed topics within Ciliophora. Ventral cirral patterns are the most important characters for dividing orders of this group. However, these patterns are susceptible to convergent evolution, which greatly reduces their reliability as phylogenetic markers (Berger 2006; Lynn 2008). In addition, phylogenetic trees based on SSU rRNA gene sequences produce poor resolution with low support values on many nodes (Schmidt et al. 2007).

Since 2006, we have submitted to GenBank 207 SSU rRNA gene sequences, 97 internal transcribed spacer (ITS)5.8S rRNA gene sequences and 87 large subunit ribosomal RNA (LSU rRNA) gene sequences of hypotrichs. A total of 48 papers focused mainly or partly on the phylogeny of hypotrichs have been published based on these sequences. Several recent papers have reported on analyses of multi-gene sequence data integrated with morphological and morphogenetic characters (Fig. 1).

Most papers focused on phylogenetic assignments of species with ambiguous positions. To date, classifications of about 50 species have been resolved. For instance, morphologically Parabirojimia was thought to be a urostylid (Berger 2006; Hu et al. 2002). However, it possesses some unique morphogenetic features, such as the origin of the transverse cirri (Hu et al. 2002). Our molecular phylogenetic study revealed that Parabirojimia represents a unique taxon that is related to but separate from the typical urostylids, and for which the suborder Parabirojimina was established (Yi et al. 2008). In addition, some integrative studies have included both morphological descriptions and molecular phylogenies when new species or genera were reported (e.g. Fan et al. 2014, 2015). This involves a total of 23 species and eight genera (Apobakuella, Apogastrostyla, Apourostylopsis, Bergeriella, Heterokeronopsis, Monocoronella, Parabistichella and Paracladotricha).

Some papers aimed at resolving within-group or speciescomplex relationships. An example is the Holosticha- 
Table 1. Ciliate sequences: contribution to the GenBank rRNA gene database by authors' groups (from Yi et al. 2016).

\begin{tabular}{|c|c|c|c|c|c|c|c|c|c|}
\hline \multirow[t]{2}{*}{ Groups } & \multicolumn{3}{|c|}{ No. of SSU rDNA sequences } & \multicolumn{3}{|c|}{ No. of ITS-5.8SrDNA sequences } & \multicolumn{3}{|c|}{ No. of LSU rDNA sequences } \\
\hline & GenBank & $\begin{array}{l}\text { Authors' } \\
\text { groups }\end{array}$ & $\begin{array}{l}\text { Ratio of our } \\
\text { sequences in } \\
\text { GenBank }\end{array}$ & GenBank & $\begin{array}{l}\text { Authors' } \\
\text { groups }\end{array}$ & $\begin{array}{l}\text { Ratio of our } \\
\text { sequences in } \\
\text { GenBank }\end{array}$ & GenBank & $\begin{array}{l}\text { Authors' } \\
\text { groups }\end{array}$ & $\begin{array}{l}\text { Ratio of our } \\
\text { sequences in } \\
\text { GenBank }\end{array}$ \\
\hline Litostomatea & 358 & 54 & $15 \%$ & 127 & 6 & $5 \%$ & 17 & 14 & $82 \%$ \\
\hline Hypotrichia \& Euplotia & 705 & 207 & $29 \%$ & 286 & 97 & $34 \%$ & 113 & 87 & $77 \%$ \\
\hline Oligotrichia s.1. & 933 & 43 & $5 \%$ & 528 & 39 & $7 \%$ & 24 & 24 & $100 \%$ \\
\hline Phyllopharyngea & 140 & 76 & $54 \%$ & 9 & 4 & $44 \%$ & 7 & 6 & $86 \%$ \\
\hline Nassophorea & 18 & 10 & $56 \%$ & 4 & 4 & $100 \%$ & 5 & 5 & $100 \%$ \\
\hline Prostomatea & 54 & 10 & $19 \%$ & 4 & 4 & $100 \%$ & 5 & 5 & $100 \%$ \\
\hline Karyorelictea & 59 & 27 & $46 \%$ & 3 & 2 & $67 \%$ & 1 & 1 & $100 \%$ \\
\hline Heterotrichea & 179 & 24 & $13 \%$ & 83 & 7 & $8 \%$ & 8 & 8 & $100 \%$ \\
\hline Peritrichia & 261 & 20 & $8 \%$ & 230 & 14 & $6 \%$ & 40 & 6 & $15 \%$ \\
\hline Scuticotiliatia & 206 & 78 & $38 \%$ & 89 & 49 & $55 \%$ & 35 & 35 & $100 \%$ \\
\hline Peniculia & 154 & 20 & $13 \%$ & 507 & 3 & $1 \%$ & 3 & 2 & $67 \%$ \\
\hline
\end{tabular}

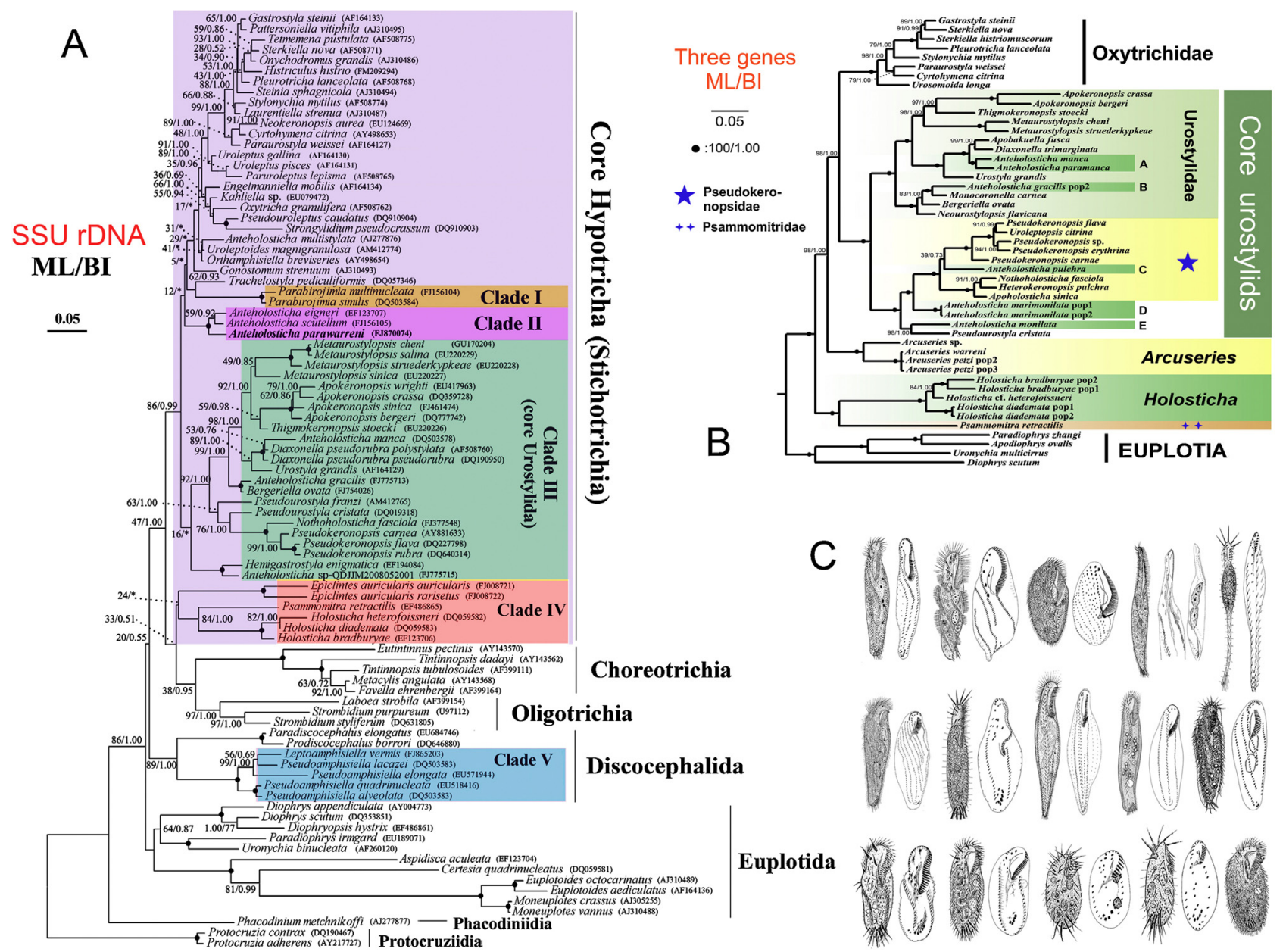

Fig. 1. Phylogenetic studies of hypotrichs. (A) Phylogenetic relationships focusing on the order Urostylida inferred from SSU rRNA gene sequences (from Yi and Song 2011); (B) Phylogenetic relationships focusing on Holosticha-complex inferred from SSU rRNA, 5.8S rRNA and LSU rRNA gene sequences (from Zhao et al. 2015); (C) Morphology of known genera in subclass Hypotrichia.

complex. Historically, all hypotrichs with three frontal cirri, transverse cirri, and a zigzag midventral complex were assigned to the genus Holosticha (Hu and Song 2001;
Berger 2006). In 2003, Berger divided this genus into four genera: Holosticha, Anteholosticha, Biholosticha and Caudiholosticha, having concluded that Holosticha-complex was a 


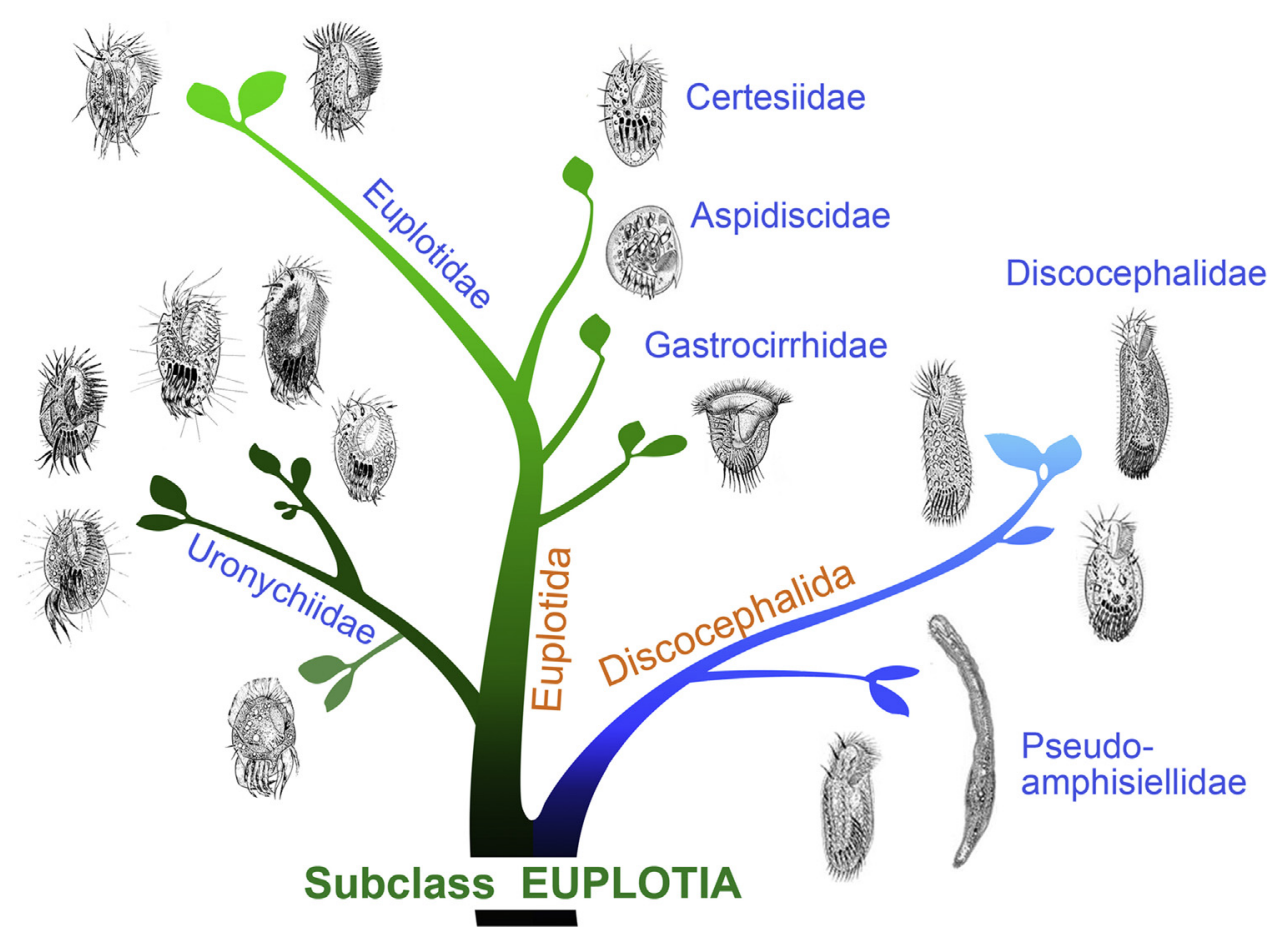

Fig. 2. Hypothetical evolution based on morphological and molecular data to show the relationships of orders and families within subclass Euplotia. Insets show the morphology of representative genera of seven families.

poorly characterized taxon based on an unspecified combination of plesiomorphies (Berger 2003). Over a period of several years we collected representative species of Holosticha and Anteholosticha and confirmed the validity of these genera based on their molecular phylogeny ( $\mathrm{Lv}$ et al. 2015; Yi et al. 2010; Zhao et al. 2015). Additionally, two new genera, i.e. Nothoholosticha and Arcuseries, which have similar morphological characters to other members of the Holosticha-complex species but could not be assigned into any of the four constituent genera, were established (Huang et al. 2014).

The increasing availability of sequences in GenBank provided the opportunity to investigate evolutionary relationships among and within higher level taxa, for instance, monophylies of the orders Urostylida, Stichotrichida and Sporadotrichida (Yi and Song 2011; Huang et al. 2014). Phylogenetic investigations of urostylids indicated that the order Urostylida is not monophyletic, although a core group was always robustly recovered (Yi and Song 2011; Huang et al. 2014). The genera Uroleptus and Paruroleptus, which are traditionally classified as urostylids, formed a sister group with the oxytrichids (Yi and Song 2011; Huang et al. 2014). Similarly, the genera Leptoamphisiella and Pseudoamphisiella should be assigned to the order Discocephalida rather than the order Urostylida (Yi and Song 2011).

Studies on sporadotrichids have revealed that the order Sporadotrichida and the family Oxytrichidae are both polyphyletic, supported the monophyly of the family Trachelostylidae, and confirmed the validity of the family Gonostomatidae (Hu et al. 2011; Huang et al. 2016). Stud- ies on the order Stichotrichida have dealt with the familial placement of various stichotrichid genera and the systematics of the families Amphisiellidae and Trachelostylidae (Yi and Song 2011; Huang et al. 2014). We have also demonstrated that members of the genus Amphisiella are separated into two clades in phylogenetic trees, corroborated by differences in cortical granule distribution (Huang et al. 2016).

Numerous unresolved phylogenetic problems, for example, how to outline orders and families better, are still present in Hypotrichia, even though this subclass is one of best-studied groups within the Ciliophora. Future integrative studies, combining phylogenomic data, multiple gene sequences and detailed morphological and morphogenetic characters are expected to help resolve such problems.

\section{Phylogenetic Studies of Euplotia}

The subclass Euplotia (syn. Hypotrichia sensu Lynn 2008) was resurrected in the classification system of Adl et al. (2012). It currently comprises two orders, Euplotida and Discocephalida, and seven families, Aspidiscidae, Certesiidae, Euplotidae, Gastrocirrhidae, Uronychiidae, Pseudoamphisiellidae and Discocephalidae (Gao et al. 2016a; Li et al. 2009a; Lynn 2008). This is considered to be one of the most confused assemblages of ciliates with a high degree of species diversity and wide distribution in freshwater, terrestrial and marine habitats. In the genus Euplotes, almost 150 species and sub-species have been recognized (Berger 2001; Jiang et al. 2010). Meanwhile, novel 

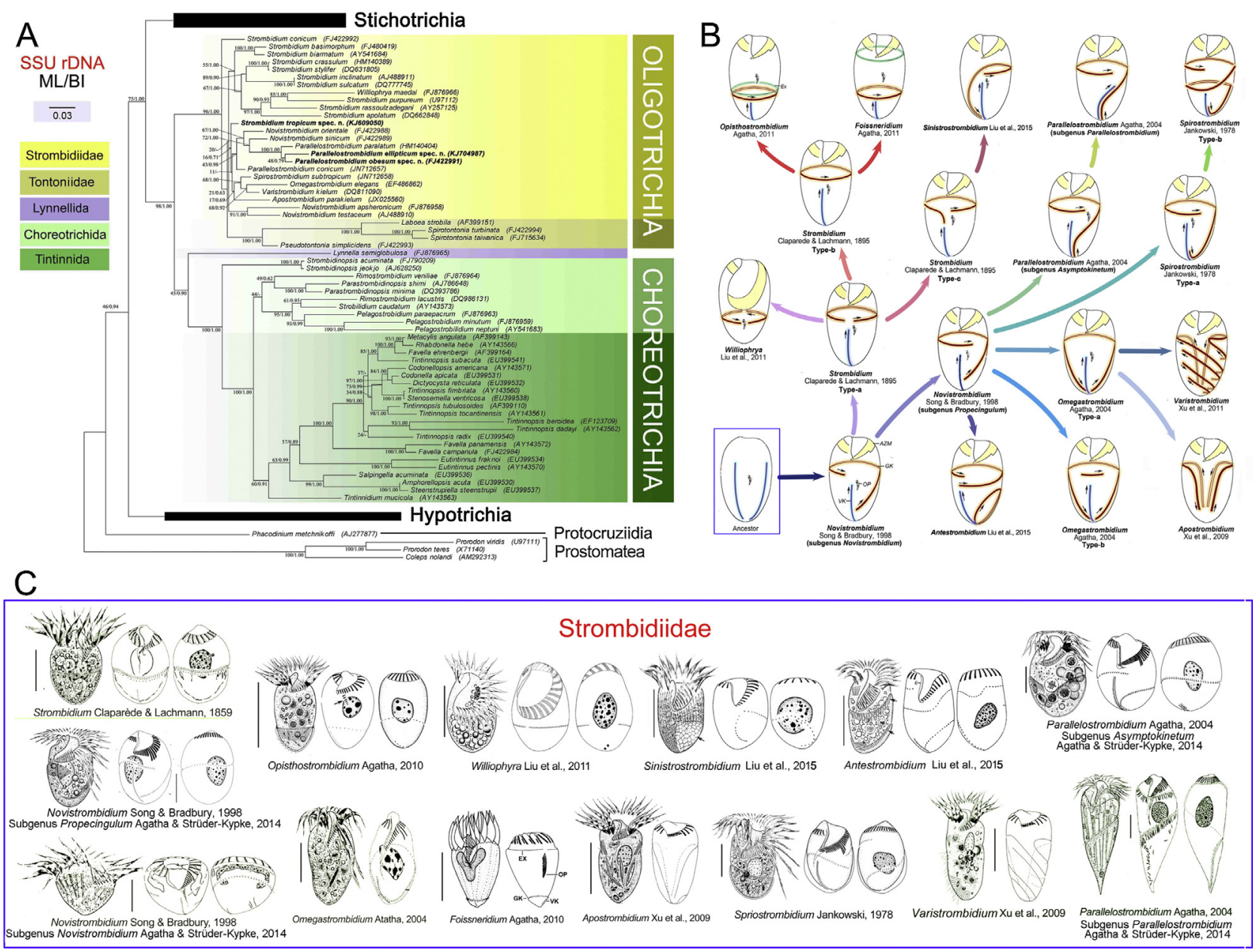

Fig. 3. Phylogenetic studies of oligotrichs and choreotrichs. (A) Phylogenetic tree inferred from SSU rRNA gene sequences of subclasses Oligotrichia and Choreotrichia (from Liu et al. 2015c). (B) Hypothetical evolution of Strombidiidae (from Liu et al. 2015b). (C) Morphology of known genera in family Strombidiidae.

species and genera are being described at a brisk rate (e.g. Hu 2008; Jiang and Song 2010; Lobban et al. 2005; Luo et al. 2014). However, phylogenetic relationships among euplotians are largely unresolved mainly due to the unavailability of gene sequences of the majority of morphospecies and disagreements among conclusions based on morphological, morphogenetic and single-gene data (Miao et al. 2007; Yi et al. 2009).

During the last two decades, we have published more than 130 multiple gene sequences of identified species with detailed morphological information (e.g. Liu et al. 2015a; Shen et al. 2009; Song et al. 2004). This accounts for more than $60 \%$ of SSU rRNA gene records and $80 \%$ of ITS-5.8S rRNA, LSU rRNA gene, and alpha-tubulin gene sequences of euplotians in the GenBank database. Nevertheless, molecular data are still available for less than $30 \%$ of euplotian morphospecies. Based on concatenated data from the authors' groups, the main findings concerning the systematics of the Euplotia are as follows (see also Fig. 2): (1) the subclass Euplotia and its two orders, Euplotida and Discocephalida, are all monophyletic based on phylogenetic analyses of con- catenated data of four genes (Gao et al. 2016a); (2) all seven families are well-supported clades in the SSU rRNA gene tree, whereas the monophyly of Uronychiidae is not recovered in trees inferred from limited sampling of other gene markers (Huang et al. 2012; Liu et al. 2015a; Miao et al. 2011; Yi et al. 2009); (3) LSU rRNA gene data and concatenated data of three rRNA genes fully support the monophyly of Paradiophrys and the establishment of Apodiophrys and Diophryopsis, although none of these genera are monophyletic in the SSU rRNA gene tree (Huang et al. 2012; Jiang and Song 2010; Jiang et al. 2011); (4) the validity of the genera Euplotopsis, Euplotoides, and Moneuplotes (Borror and Hill 1995; Jankowski 1978) is not supported by molecular data and we therefore proposed to remerge them into a single genus Euplotes (Liu et al. 2015a; Yi et al. 2009); (5) the hypothesis based on morphological data that discocephalids and pseudoamphisiellids are closely related was consistently supported in both single-gene and concatenated trees (Gao et al. 2016a; Miao et al. 2011).

It is noteworthy that the present molecular phylogeny should not be over interpreted as some gene sequences 
in GenBank are likely to be from misidentified morphospecies. Therefore, additional integrative information of phylogenomic data or multiple gene markers from the same DNA source, and detailed morphological and morphogenetic characters, will help in understanding the phylogenetic relationships within Euplotia.

\section{Phylogenetic Studies of Oligotrichia and Choreotrichia}

The oligotrichs and choreotrichs are ecologically important components of the marine plankton as together they graze $\sim 70 \%$ of the primary production and transfer the energy in the phytoplankton-based food web (Pierce and Turner 1992). Based on both morphological and genetic data the subclasses Oligotrichia and Choreotrichia, along with the monospecific order Lynnellida, comprise a total of at least 1687 species, including 133 species of oligotrichs, over 1500 species of loricate choreotrichs (tintinnids) and 53 species of aloricate choreotrichs (Agatha 2011; Agatha and Strüder-Kypke 2014; Gao et al. 2016a, 2016b). The molecular phylogenies often reveal unexpected relationships that do not map onto cladograms of these groups based on morphological data, especially at genus level (Agatha and Strüder-Kypke, 2012; McManus and Katz 2009). These inconclusive results are probably caused by the considerable morphological convergence among these forms, although other possible explanations are limited taxon representation in the datasets and high genetic variation among the genera.

Over the last decade, genomic DNA of 157 oligotrichous species/populations has been sequenced by our group, including that of 27 new species. About 43 sequences of the SSU rRNA gene, 39 sequences of the ITS-5.8S rRNA gene and 24 sequences of the LSU rRNA gene have been submitted to the GenBank database. Based on these and other published data, we have carried out numerous molecular phylogenetic studies on oligotrichs and choreotrichs (Gao et al. 2009; Liu et al. 2015b; Song et al. 2015a). Main conclusions include that the subclasses Oligotrichia and Choreotrichia are both strongly supported monophylies and are sister groups, whereas the systematic position of Lynnella is ambiguous and unstable (Liu et al. 2011). Recent phylogenetic analyses integrating both the molecular and morphological data indicated that Lynnella might represent a new order separated from both the subclasses Oligotrichia and Choreotrichia (Liu et al. 2015b).

Within the subclass Oligotrichia, the systematic relationships of the families Tontoniidae and Strombidiidae were investigated. The main findings were: (1) the strombidiid genus Laboea should be transferred into the family Tontoniidae, suggesting that the spiralled girdle kinety is probably a synapomorphy rather than a convergent feature as previously speculated for tontoniids and Laboea (Agatha 2004), and the tail was likely lost during the evolution of Laboea species (Gao et al. 2009); (2) the family Strombidiidae is polyphyletic and the genus Strombidium is so genetically diverse that should probably be split into several yet to be defined genera (Liu et al. 2015c; Song et al. 2015a, 2015b); (3) our phylogenetic analyses support a new evolutionary hypothesis of the 12 known strombidiid genera, i.e. that the ciliary pattern of the subgenus Novistrombidium probably represents the ancestral state in the evolution of strombidiids, which then gave rise to two main groups, one composed of Strombidium-like genera and the other non-Strombidium-like genera (Fig. 3; Liu et al. 2015b).

Within the subclass Choreotrichia, the monophyly of the order Choreotrichida was not recovered because the family Strobilidiidae groups with the tintinnids rather than with strombidinopsid genera. Other main findings were that: (1) the order Tintinnida is monophyletic, while the family Tintinnidae might be paraphyletic; (2) the lorica-based definition for the genus Tintinnopsis is not consistent with the molecular phylogeny; (3) the codonellopsid genera Stenosemella and Codonellopsis might need to be merged into a single genus based on molecular analyses and the possession by both of a hyaline collar (Li et al. 2009b).

Despite the recent advances in the use of molecular tools for studying oligotrich and choreotrich phylogeny, the topology of the gene trees remains unstable because genetic data are unavailable for several key taxa such as Leegaardiella, Lohmanniella, and Parastrombidium. Additionally, molecular information of tintinnids is still scant relative to the large number of morphotypes currently recognized. Extensive sequence sampling of these taxa along with increases in knowledge of their taxonomy based on ultrastructure and infraciliature characters, are expected to significantly enhance our future understanding of the phylogeny of oligotrichs and choreotrichs (Agatha 2011; Santoferrara et al. 2016).

\section{Phylogenetic Studies of Peritrichia}

The peritrichs are among the most diverse and commonly observed ciliates with more than 105 genera representing over 1000 species (Foissner et al. 2010; Lynn 2008). Systematically, peritrich ciliates are generally treated as a subclass, Peritrichia, within the class Oligohymenophorea (Lynn 2008). However, phylogenetic relationships among many peritrichs remain confused because molecular, especially multi-gene, data are available for relatively few representatives.

In order to improve this situation, we have submitted to NCBI/GenBank gene sequences of numerous wellcharacterized and accurately identified peritrichs, including 20 SSU rRNA, 14 ITS1-5.8S-ITS2, and six LSU rRNA. While several of our molecular studies have provided support for some hypotheses based on morphological and/or ontogenetic characters, others have yielded radically different results. Our main results can be summarized as follows (see also Fig. 4): (1) sessilids which have stalks with con- 

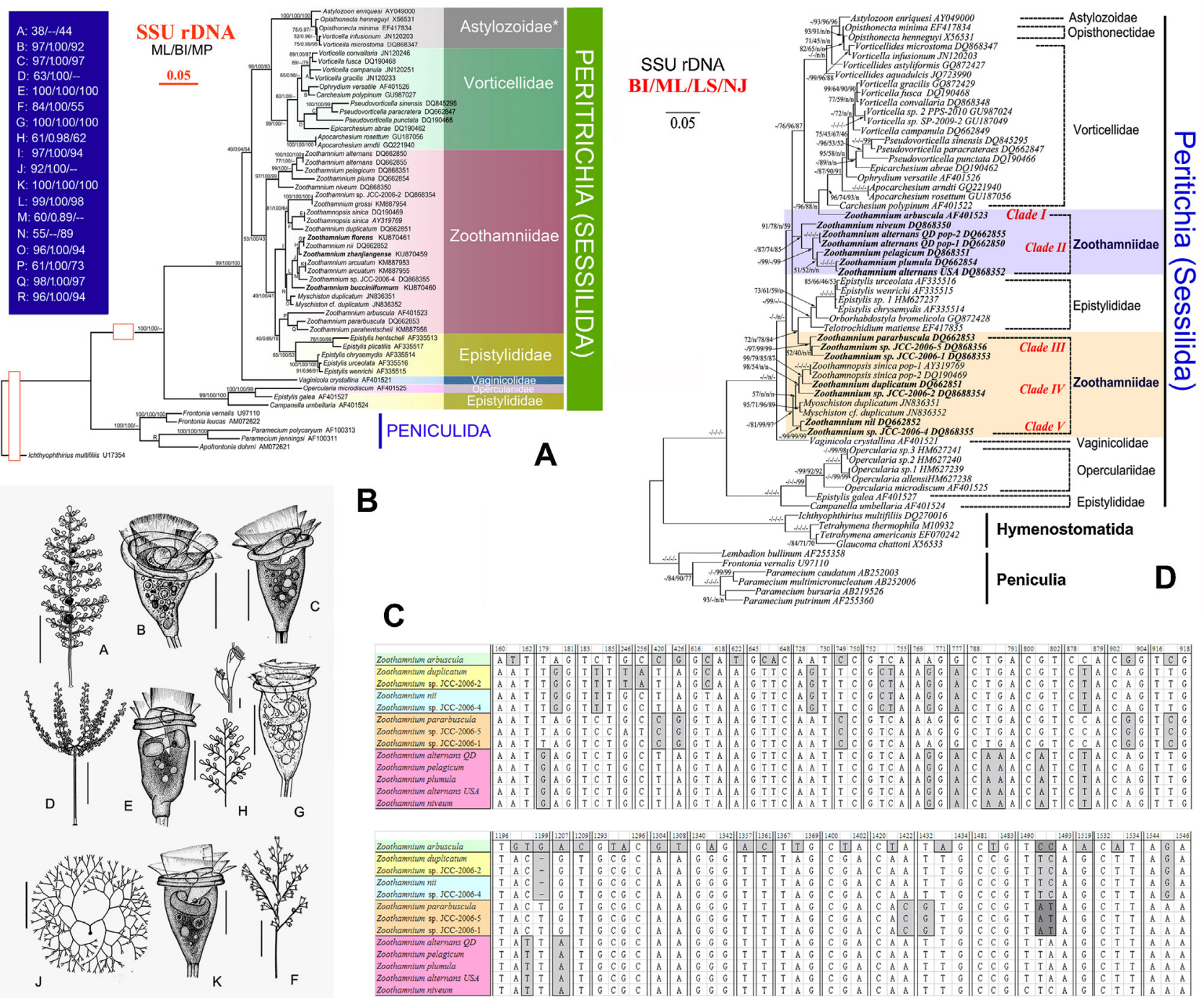

B

C
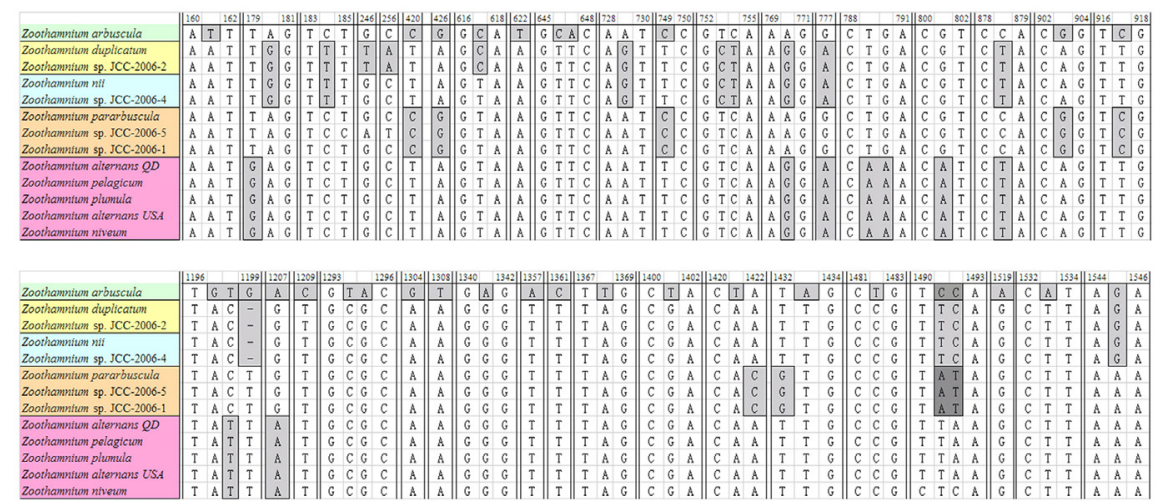

Fig. 4. Phylogenetic studies of peritrichs. (A, D) Phylogenetic trees inferred from nucleotide sequences of SSU rRNA gene showing the phylogeny of peritrichs ((A) from Shen et al. 2017; (D) from Li et al. 2015); (B) Morphology of five Zoothamnium spp.; (C) Regions of alignment of nuclear small subunit rRNA sequences of Zoothamnium spp. (from Li et al. 2015).

tinuous myonemes that contract in a zig-zag fashion form a separate clade from those which have stalks that contract in a spiral fashion, supporting the separation of the family Zoothamniidae from the family Vorticellidae (Li et al. 2015); (2) Zoothamnium exhibits a higher genetic diversity than is suggested by the gross morphology of its species ( $\mathrm{Li}$ et al. 2015; Shen et al. 2017); (3) Zoothamnium pararbuscula was established as a new species based on information derived from SSU-ITS1-5.8S rRNA gene sequence analysis and some morphological features (Ji et al. 2005).

The phylogeny of peritrichs is still subject to much debate, including whether or not the subclass Peritrichia is monophyletic (Gentekaki et al. 2017; Gong et al. 2010; Zhan et al. 2009, 2013). The possible reasons are: (1) the low number of samples which have been used in the molecular analyses may have led to erroneous conclusions; (2) the evolution rate of a given morphological character may differ among major groups. It is unlikely that the phylogeny of peritrichs will be resolved without significantly more data, both morphological and molecular, from a greater number of species.

\section{Phylogenetic Studies of Scuticociliatia}

Scuticociliates are a speciose group whose members can be found in a wide variety of aquatic and terrestrial habitats, either free-living or as parasites of aquatic animals (Liu et al. 2016; Pan et al. 2015, 2016; Song et al. 2003). They are usually very small in size and share similar morphological features, making them difficult to investigate (Fan et al. 2011; Pan et al. 2013). Moreover, molecular data are not available for most of the described morphospecies, e.g. SSU rRNA gene sequences of only about ten scuticociliate species were available in GenBank before our studies. Consequently, 

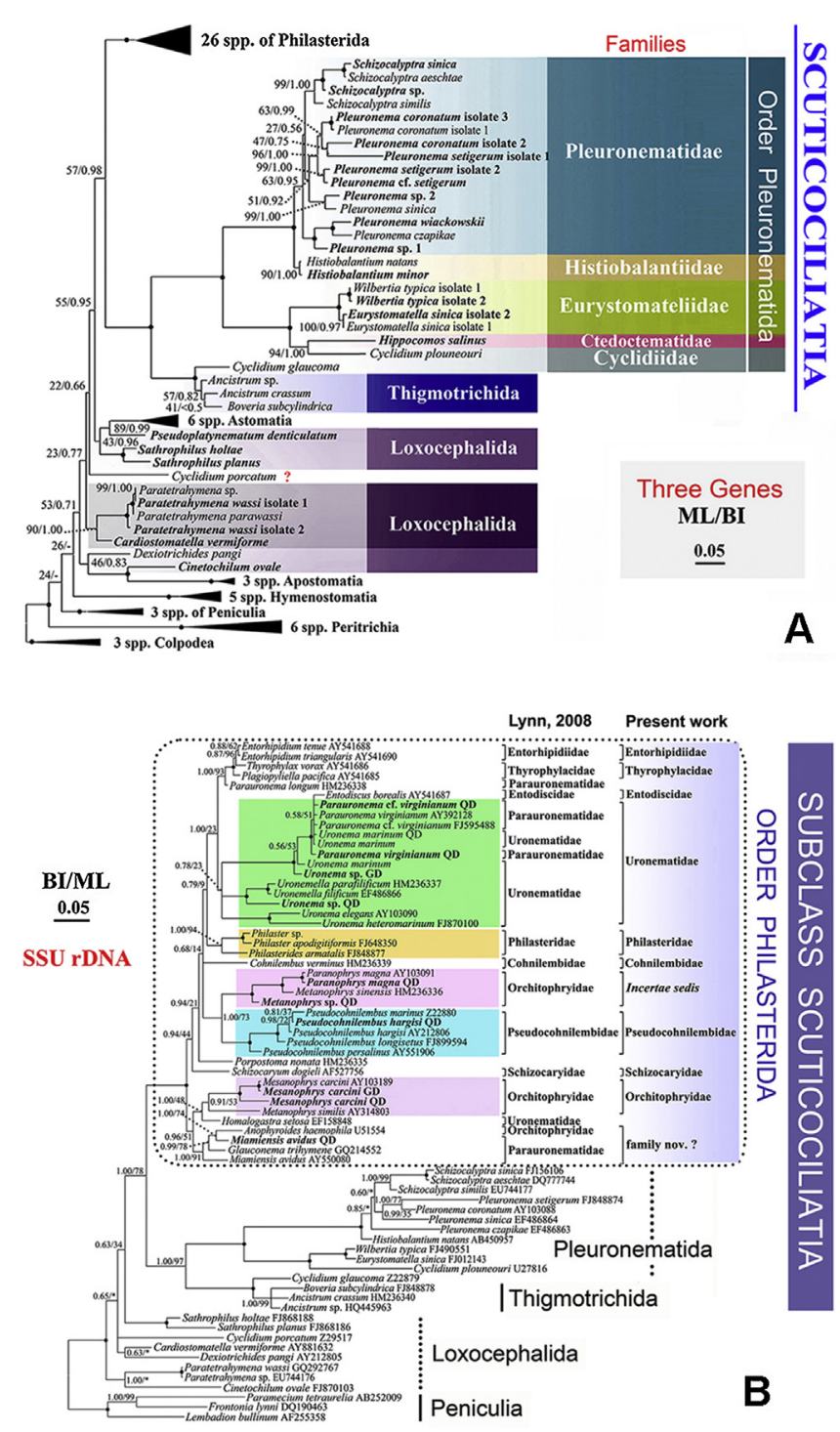
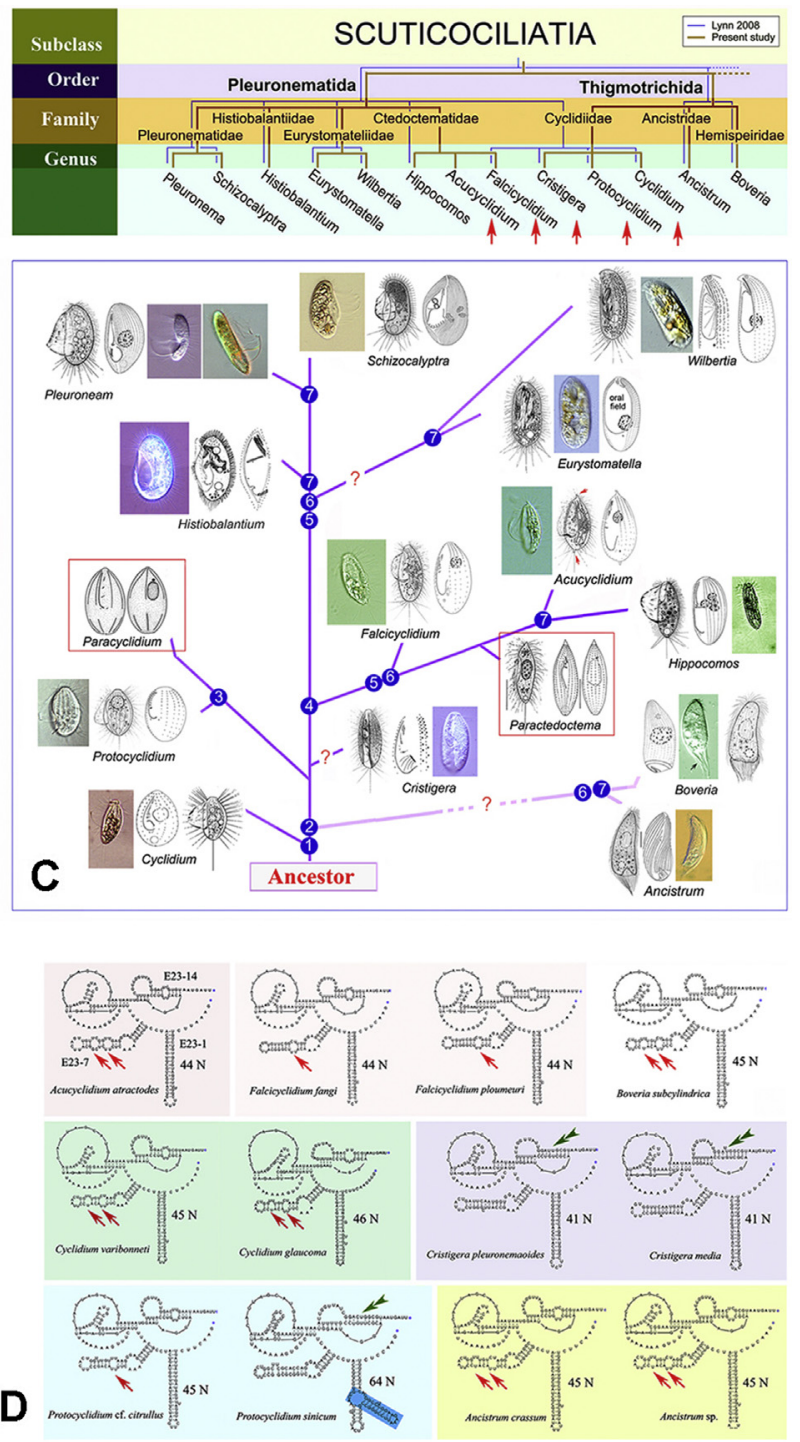

Fig. 5. Phylogenetic studies of scuticociliates. (A) Phylogenetic tree focusing on pleuronematids and loxocephalids inferred from the concatenated data of SSU rRNA, 5.8S rRNA and LSU rRNA gene sequences (from Gao et al. 2013); (B) Phylogenetic tree focusing on philasterids inferred from SSU rRNA gene sequences (from Gao et al. 2012); (C) Classification and cladogram to show the possible evolution of pleuronematid and thigmotrichid genera (from Gao et al. 2014); (D) Secondary structures of variable region 4 (V4) of the SSU rRNA of 12 scuticociliates (from Gao et al. 2014).

phylogenetic relationships within the subclass Scuticociliatia were largely unresolved (Foissner et al. 2009; Lynn and Strüder-Kypke 2005).

Over the past decade, we have expanded the taxonomic sampling of scuticociliates having isolated and characterized 61 morphospecies and provided 162 new gene sequences, including 78 SSU rRNA, 49 ITS-5.8S rRNA and 35 LSU rRNA. This includes the first molecular data of any kind for two orders, namely Thigmotrichida and Loxocephalida, and 25 genera. Phylogenetic analyses based on single-gene and concatenated data, secondary structural analyses and predicted topology tests have been carried out to expand our understanding of phylogeny within the subclass Scuticociliatia. The main results are summarized as follows (Fig. 5): (1)
The order Philasterida is a well-supported lineage although the evolutionary relationships among most of its families remain unresolved (Gao et al. 2012; Pan et al. 2013); (2) in all analyses the thigmotrichids are nested within the order Pleuronematida and so should be regarded as a suborder within Pleuronematida (Gao et al. 2014); (3) the loxocephalids are polyphyletic, being basal to the core scuticociliates and most closely related to the subclasses Astomatia and Apostomatia, and should be separated from the order Philasterida (Gao et al. 2013; Li et al. 2006; Zhang et al. 2010, 2011); (4) Parauronema is a junior synonym of Uronema; consequently, Parauronematidae becomes a junior synonym of Uronematidae (Gao et al. 2012); (5) the families Orchitophryidae, Uronematidae, Cyclidiidae, Loxocephalidae and 
Cinetochilidae are all non-monophyletic (Gao et al. 2012, 2013, 2014); (6) the genera Metanophrys, Uronema, Cyclidium, and Protocyclidium are all non-monophyletic (Gao et al. 2012, 2014); (7) four new genera were established, Eurystomatella, Wilbertia, Acucyclidium, and Paramesanophrys (Fan et al. 2011; Gao et al. 2014; Miao et al. 2010).

There are, however, still many significant challenges with the phylogeny and systematics of the scuticociliates. For example, family assignments in the order Philasterida are still uncertain, the phylogenetic positions of thigmotrichids and cyclidiids need to be revised with more evidence, loxocephalids are dispersed in different groups and need to be defined, etc. There are two main reasons for these ongoing problems: firstly, scuticociliates are generally small in size and share similar infraciliature and characters in vivo, resulting in many misidentifications that lead to errors in phylogenetic analyses; secondly, detailed morphologi$\mathrm{cal} / \mathrm{morphogenetic/molecular} \mathrm{data} \mathrm{from} \mathrm{some} \mathrm{key} \mathrm{taxa} \mathrm{are}$ still missing, including for many type species, which hinders the revision of the existing classification and systematics. To solve these problems, more taxa need to be sampled and studied in detail at the morphological, morphogenetic, and molecular levels. Moreover, the application of new technologies such as DNA-barcoding for accurate species identification and phylogenomic analyses for expanding the number of informative gene markers, are also likely to help resolve these problems.

\section{Phylogenetic Studies of the Phylum Ciliophora}

Although numerous studies on the taxonomy and systematics of ciliates have been performed and published, the vast majority of these are focused on one or a few specific groups and/or based on sequence data for a single gene, the SSU rRNA. In two recent studies, we investigated evolutionary relationships within the entire phylum Ciliophora using a taxon-rich strategy based on multiple gene loci (Gao and Katz 2014; Gao et al. 2016b).

The first of these studies included phylogenomic analyses of 537 ciliate taxa, all of which have been sampled for the SSU rRNA gene sequence and a subset of which included LSU rRNA gene and up to seven protein-coding sequences. The full data matrix and six submatrices were analysed in order to assess the impact of taxon sampling and missing data. These analyses support the bifurcation of ciliates into two major clades defined by differences in division of the somatic macronuclei: the subphyla Intramacronucleata and Postciliodesmatophora (Gao and Katz 2014; Lynn 2008). The second study focused on a full-scale classification of the Ciliophora at the level of order/family. Phylogenetic analyses were carried out based on up to four gene markers (SSU rRNA, 5.8S rRNA, LSU rRNA, alpha-tubulin) from a total of 152 species representing 110 families and 55 orders. The main findings were as follows (see also Fig. 6): (1) 14 classes were recovered including one new class, Protocruziea; (2) in addition to the two main branches (Postciliodesmatophora and Intramacronucleata), a third branch, the Mesodiniea, was identified as being basal to the other two; (3) the monophyly of the subclass Hypotrichia was supported and the newly defined order Discocephalida was revealed to be a sister clade to the euplotids, strongly suggesting the separation of discocephalids from the hypotrichs; (4) Phacodiniidia and Protohypotrichia were consistently recovered as a clade that is basal to the core spirotricheans; (5) the newly established order Lynnellida is placed between the Oligotrichia and Choreotrichia; (6) the separation of the mobilids from the sessilid peritrichs was not supported by evidence from morphology, ontogenesis or molecular analyses; (7) within the subclass Scuticociliatia, the paraphyletic order Loxocephalida is basal to the main scuticociliate assemblage, whereas the thigmotrichs are placed within the order Pleuronematida; (8) the monophyly of classes Phyllopharyngea, Karyorelictea, Armophorea, Prostomatea, Plagiopylea, Colpodea and Heterotrichea were confirmed; (9) the ambiguous genera Askenasia, Cyclotrichium, Paraspathidium and Plagiocampa showed close affiliation to the well-known plagiopyleans; (10) the validity of the subclass Rhynchostomatia, which is basal to the Litostomatea, was supported; and (11) the systematic positions of Halteria and Licnonophoria (represented by Licnophora) remain unresolved due to extremely contradictory information from morphology, ontogenesis and SSU rRNA gene sequence data, and are thus regarded as incertae sedis within Spirotrichea (Gao et al. 2016b).

Numerous phylogenetic and systematic problems within the ciliates are still largely unresolved. Notable among these are the systematic positions of genera such as Halteria, Licnophora, Protocruzia, Mesodinium, and Urocentrum, phylogenetic relationships within the Prostomatea-Plagiopylea group, the assignments of the taxa in Nassophorea, the evolutionary relationships among some classes, etc. Part of the reason for this is that molecular information of many taxa is unavailable and phylogenetic analyses have mainly focused on few genes. Phylogenomic analyses are now increasingly applied for investigating evolutionary relationships among ciliates (Feng et al. 2015; Gao et al. 2014; Gentekaki et al. 2014, 2017). This will help significantly to resolve most if not all of the questions mentioned above as genome/transcriptome data become available for more taxa.

\section{Barcoding Ciliates: Exploring Potential Candidate Genes}

The use of DNA barcoding, as a molecular tool to aid in the discrimination of species, was introduced by Hebert et al. (2003). The mitochondrial cytochrome c oxidase subunit 1 ( $\operatorname{cox} 1$ ) gene was chosen as the preferred marker because of its central role in the metabolism of aerobic eukaryotic organ- 

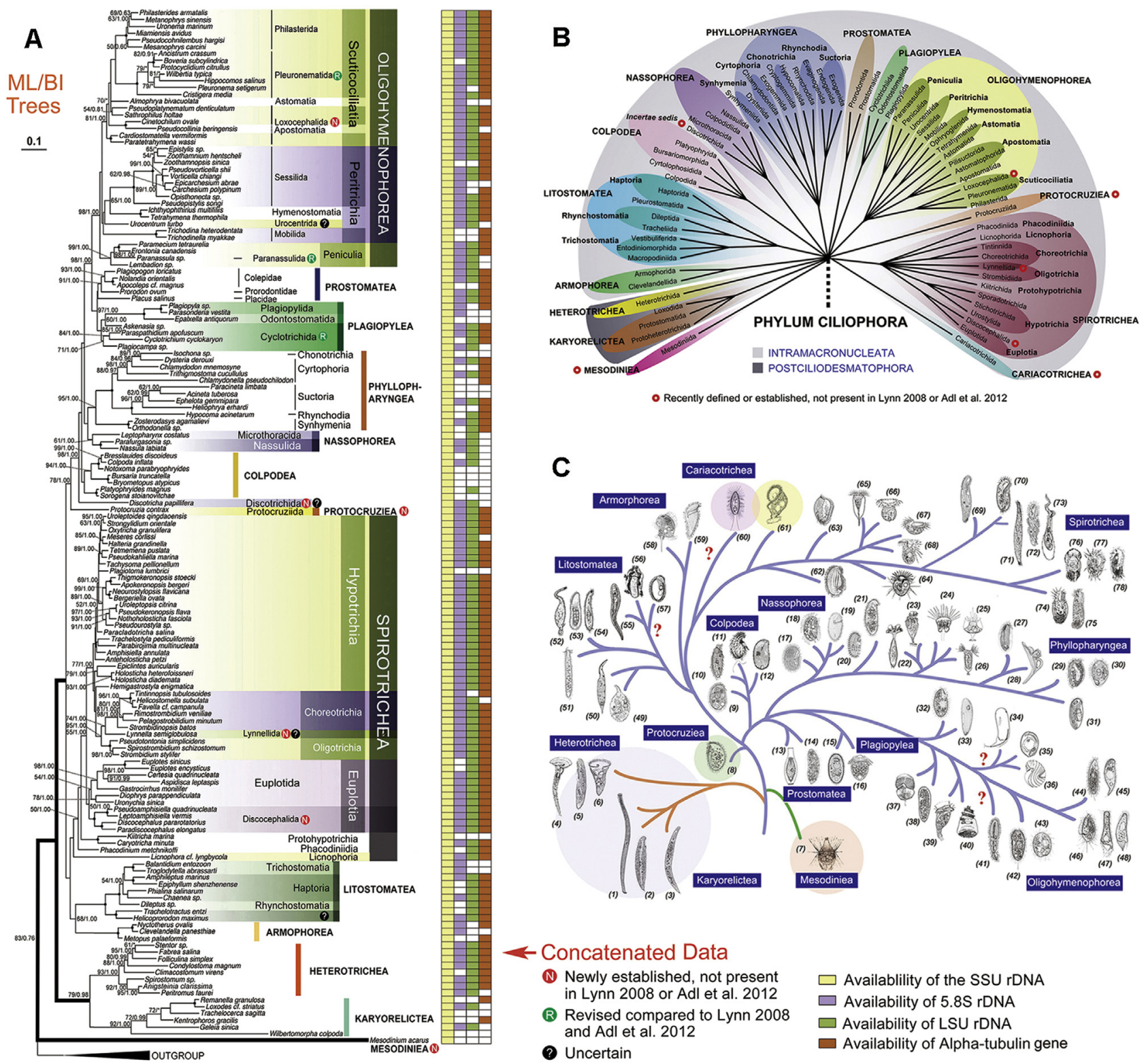

Fig. 6. Molecular phylogeny of the phylum Ciliophora (from Gao et al. 2016b). (A) Maximum likelihood (ML) tree reconstructed using 152 ciliates and concatenated gene sequence data, the SSU rRNA gene sequence is available for all the taxa whereas the 5.8S rRNA, LSU rRNA and alpha-tubulin gene sequences are available for only a subset of these taxa. (B) Systematic scheme for the phylum Ciliophora at order level. (C) Hypothetical evolution of ciliated protozoa based on both morphological and molecular data to show the relationship and the positions of the taxa at order level.

isms and therefore its presence in almost all eukaryotes. The cox 1 gene is now extensively used as the standard barcode gene for almost all animal groups, although other genes are preferred for plants $(r b c \mathrm{~L})$ and fungi (ITS region). There is, however, no standard barcode for the protists, largely due to their extreme diversity and the levels of genetic divergence between and within major protistan groups (Pawlowski et al. 2012). Barcoding work on ciliates is still at the initial stage even though there are some pioneering works that evaluate the utility of mitochondrial candidate genes (e.g. Barth et al. 2006; Chantangsi et al. 2007; Kher et al. 2011; Strüder-Kypke and Lynn 2010). To date, however, no single set of molecular markers has been confirmed to work in all ciliate lineages.

In a pilot study, we focused on assessing genetic divergence of the cox 1 gene within individuals and how its presence might affect species identification and population structure analyses (Fig. 7). The results demonstrate that although heteroplasmy exists in Paramecium, cox 1 is nevertheless a suitable marker for resolving inter- and intra-specific relationships among Paramecium species (Barth et al. 2006; Zhao et al. 2013). Due to its high divergence even within members of the same taxon, however, the difficulty of designing universal cox 1 gene primers hampers its utility for all cil- 
A
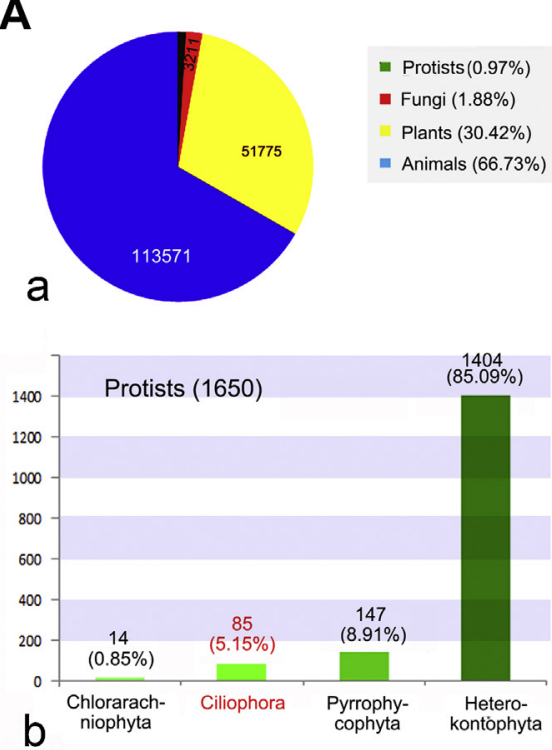
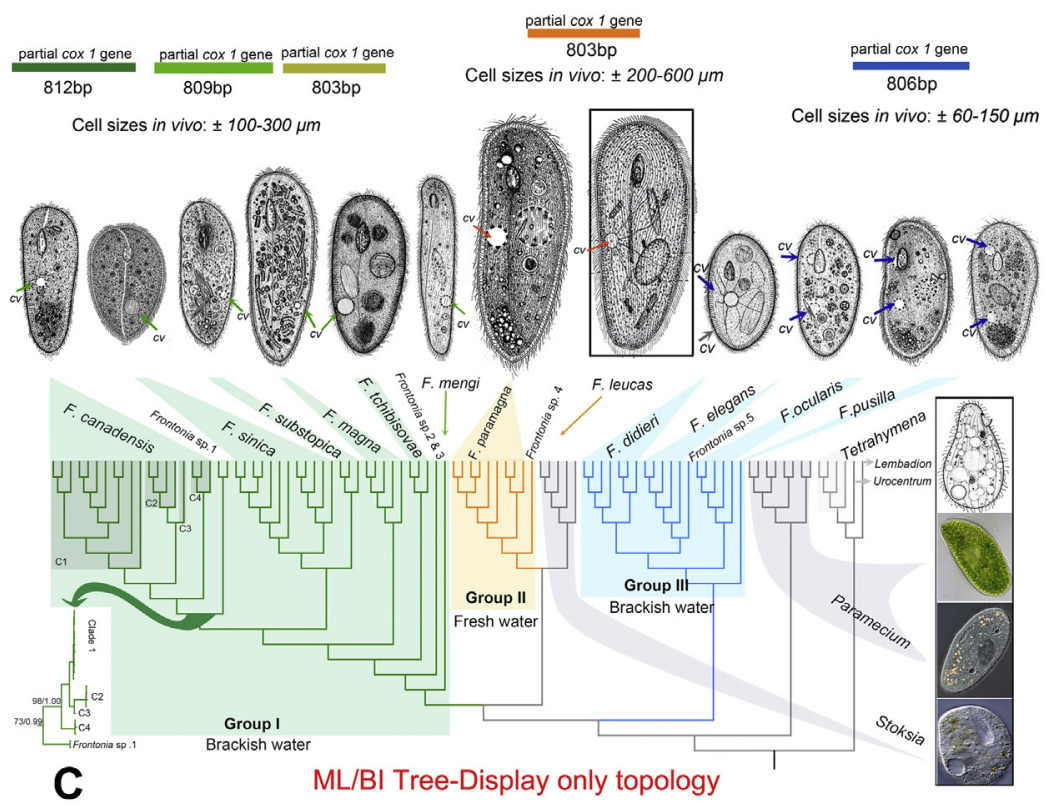
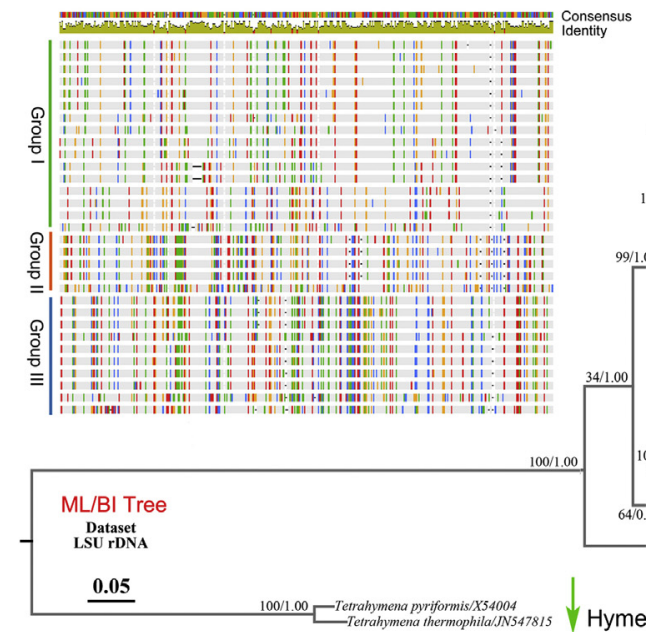

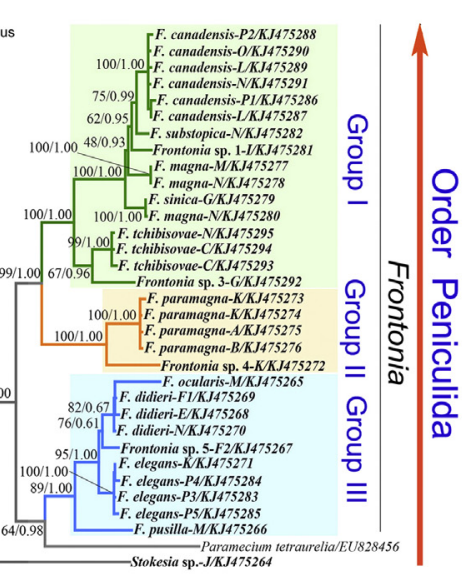

Hymenostomatida

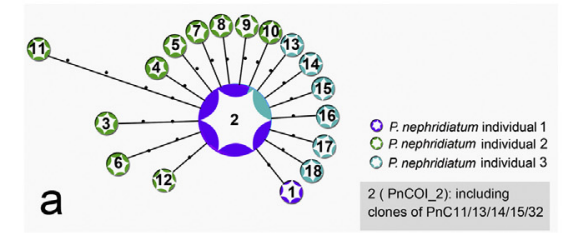

b

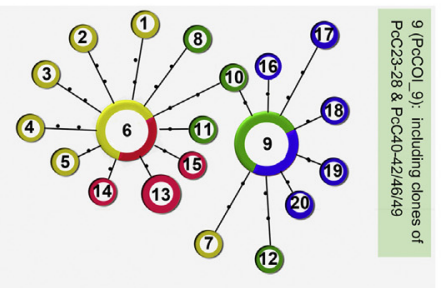

6 (PcCOI6): $\quad$ O P. caudatum individual 1

including clones of

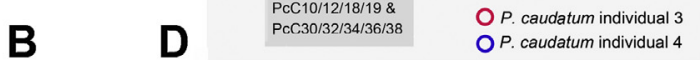

Fig. 7. Barcoding research on ciliates. (A) Current state of barcoding research on protists (a) and ciliates (b). (B) Evidence that D1-D2 region of LSU rRNA gene shows promising results for species delineation (from Zhao et al. 2016). (C) Integrated information suggests that cox 1 is suitable for Frontonia species delineation (from Zhao et al. 2016). (D) Evidence that cox 1 heteroplasmy exists in Paramecium species (from Zhao et al. 2013).

iates. Consequently, we tested various other gene markers in an effort to identify the ideal barcoding candidate for ciliate species identification. For this, we investigated wellcharacterized members of the species-rich genus Frontonia in order to test the accuracy and efficacy of different candidates. These studies revealed that the mitochondrial $\operatorname{cox} 1$ gene, the nuclear ITS1 and ITS2 regions and the hypervariable D1-D2 region of the LSU rRNA gene are promising candidates for species delineation. Of these, the D1-D2 region of the LSU rRNA gene has the greatest potential to build a barcoding reference database since it can be obtained using universal PCR primers (Zhao et al. 2016). Group-specific barcodes are still being validated among other protist lineages (Pawlowski et al. 2012), and our case studies in ciliates provide valuable data on the appropriateness of different genetic markers to the barcoding enterprise.

At present, the construction of a DNA barcode library and its performance for identifying cryptic species is still at the exploratory stage. Besides, we also have to take into consideration that the accuracy of barcoding datasets is dependent on recovery of as many taxonomically verified specimens as possible. Therefore, we can foresee daunting challenges, such as universal primer design and voucher specimen identification, when accomplishing the Ciliate Barcoding Project. Here, we recommend the development of group-specific primers, which may help resolve failed amplification of particular taxa. Last but not least, a solid taxonomic foundation is prerequisite in barcoding ciliates and new barcoding data are 
reliable only when the species is identified accurately based on traditional taxonomic methods.

\section{Acknowledgements}

The IRCN-BC program supported by the NSF (USA) and NSFC (China) is highly acknowledged. This work is also supported by the Natural Science Foundation of China (31430077, 31572230, 31401963, 31471973, 41576124), International Exchanges Scheme supported by the Royal Society/Natural Science Foundation of China (31411130122), a BBSRC China Partnering Award, the Applied Basic Research Plan of Qingdao (15-12-1-1-jch), the Fundamental Research Funds for the Central Universities (201564022), and AoShan Talents Program Supported by Qingdao National Laboratory for Marine Science and Technology (No.2015ASTP). The authors extend their sincere appreciation to the Deanship of Scientific Reserarch at King Saud University for funding this work through Research Group (RGP-242).

\section{References}

Adl, S.M., Simpson, A.G.B., Lane, C.E., Lukeš, J., Bass, D., Bowser, S.S., et al., 2012. The revised classification of eukaryotes. J. Eukaryot. Microbiol. 59, 429-493.

Agatha, S., 2004. A cladistic approach for the classification of oligotrichid ciliates (Ciliophora: Spirotricha). Acta Protozool. 43, 201-217.

Agatha, S., 2011. Global diversity of aloricate Oligotrichea (Protista, Ciliophora, Spirotricha) in marine and brackish sea water. PLoS One 6, e22466.

Agatha, S., Strüder-Kypke, M.C., 2012. Reconciling cladistic and genetic analyses in choreotrichid ciliates (Ciliophora, Spirotricha, Oligotrichea). J. Eukaryot. Microbiol. 59, 325-350.

Agatha, S., Strüder-Kypke, M.C., 2014. What morphology and molecules tell us about the evolution of Oligotrichea (Protista, Ciliophora). Acta Protozool. 53, 77-90.

Barth, D., Krenek, S., Fokin, S.I., Berendonk, T.U., 2006. Intraspecific genetic variation in Paramecium revealed by mitochondrial cytochrome c oxidase I sequences. J. Eukaryot. Microbiol. 53, 20-25.

Berger, H., 2001. Catalogue of Ciliate Names 1. Hypotrichs. Salzburg, Verlag Helmut Berger.

Berger, H., 2003. Redefinition of Holosticha Wrzesniowski, 1877 (Ciliophora, Hypotricha). Eur. J. Protistol. 39, 373-379.

Berger, H., 1999. Monograph of the Oxytrichidae (Ciliophora, Hypotrichia). Monogr. Biol. 78, 1-1080.

Berger, H., 2006. Monograph of the Urostyloidea (Ciliophora, Hypotricha). Monogr. Biol. 85, 1-1304.

Berger, H., 2008. Monograph of the Amphisiellidae and Trachelostylidae (Ciliophora, Hypotricha). Monogr. Biol. 88, 1-737.

Berger, H., 2011. Monograph of the Gonostomatidae and Kahliellidae (Ciliophora, Hypotricha). Monogr. Biol. 90, 1-741.
Borror, A.C., Hill, B.F., 1995. The order Euplotida (Ciliophora): taxonomy, with division of Euplotes into several genera. J. Eukaryot. Microbiol. 42, 457-466.

Chantangsi, C., Lynn, D.H., Brandl, M.T., Cole, J.C., Hetrick, N., Ikonomi, P., 2007. Barcoding ciliates: a comprehensive study of 75 isolates of the genus Tetrahymena. Int. J. Syst. Evol. Microbiol. 57, 2412-2425.

Chen, X., Ma, H., Al-Rasheid, K.A.S., Miao, M., 2015. Molecular data suggests the ciliate Mesodinium (Protista: Ciliophora) might represent an undescribed taxon at class level. Zool. Syst. 40, 31-40.

Chen, X., Pan, H.B., Huang, J., Warren, A., Al-Farraj, S.A., Gao, S., 2016. New considerations on the phylogeny of cyrtophorian ciliates (Protozoa, Ciliophora): expanded sampling to understand their evolutionary relationships. Zool. Scr. 45, 334-348.

Corliss, J.O., 1979. The Ciliated Protozoa: Characterization, Classification and Guide to the Literature. Pergamon Press, Oxford.

Fan, X., Hu, X., Al-Farraj, S.A., Clamp, J.C., Song, W.B., 2011. Morphological description of three marine ciliates (Ciliophora, Scuticociliatia), with establishment of a new genus and two new species. Eur. J. Protistol. 47, 186-196.

Fan, Y., Pan, Y., Huang, J., Hu, X., Lin, X., Warren, A., 2014. Molecular phylogeny and taxonomy of two novel brackish water hypotrich ciliates with the establishment of a new genus, Antiokeronopsis gen. n. (Ciliophora, Hypotrichia). J. Eukaryot. Microbiol. 61, 449-462.

Fan, Y., Zhao, X., Hu, X., Miao, M., Warren, A., Song, W.B., 2015. Taxonomy and molecular phylogeny of two novel ciliates with establishment of a new genus, Pseudogastrostyla n. g. (Ciliophora, Hypotrichia, Oxytrichidae). Eur. J. Protistol. 51, 374-385.

Feng, J., Jiang, C., Warren, A., Tian, M., Cheng, J., Liu, G., Xiong, J., Miao, W., 2015. Phylogenomic analyses reveal subclass Scuticociliatia as the sister group of subclass Hymenostomatia within class Oligohymenophorea. Mol. Phylogenet. Evol. 90, 104-111.

Foissner, W., Kusuoka, Y., Shimano, S., 2009. Morphological and molecular characterization of Histiobalantium natans viridis Kahl, 1931 (Ciliophora, Scuticociliatia). Eur. J. Protistol. 45, 193-204.

Foissner, W., Blake, N., Wolf, K., Breiner, H.W., Stoeck, T., 2010. Morphological and molecular characterization of some peritrichs (Ciliophora Peritrichida) from tank bromeliads, including two new genera: Orborhabdostyla and Vorticellides. Acta Protozool. 48, 291-319.

Gao, F., Gao, S., Wang, P., Katz, L.A., Song, W.B., 2014. Phylogenetic analyses of cyclidiids (Protista, Ciliophora, Scuticociliatia) based on multiple genes suggest their close relationship with thigmotrichids. Mol. Phylogenet. Evol. 75, 219-226.

Gao, F., Katz, L.A., 2014. Phylogenomic analyses support the bifurcation of ciliates into two major clades that differ in properties of nuclear division. Mol. Phylogenet. Evol. 70, 240-243.

Gao, F., Katz, L.A., Song, W.B., 2012. Insights into the phylogenetic and taxonomy of philasterid ciliates (Protozoa Ciliophora, Scuticociliatia) based on analyses of multiple molecular markers. Mol. Phylogenet. Evol. 64, 308-317.

Gao, F., Katz, L.A., Song, W.B., 2013. Multigene-based analyses on evolutionary phylogeny of two controversial ciliate orders: Pleuronematida and Loxocephalida (Protista, Ciliophora, Oligohymenophorea). Mol. Phylogenet. Evol. 68, 55-63.

Gao, F., Li, J., Song, W., Xu, D., Warren, A., Yi, Y., Gao, S., 2016a. Multi-gene-based phylogenetic analysis of oligotrich cil- 
iates with emphasis on two dominant groups: cyrtostrombidiids and strombidiids (Protozoa, Ciliophora). Mol. Phylogenet. Evol. 105, 141-150.

Gao, F., Warren, A., Zhang, Q., Gong, J., Miao, M., Sun, P., Xu, D., Huang, J., Yi, Z., Song, W.B., 2016b. The all-data-based evolutionary hypothesis of ciliated protists with a revised classification of the Phylum Ciliophora (Eukaryota, Alveolata). Sci. Rep. 6, 24874.

Gao, S., Gong, J., Lynn, D., Lin, X., Song, W.B., 2009. An updated phylogeny of oligotrich and choreotrich ciliates (Protozoa Ciliophora, Spirotrichea) with representative taxa collected from Chinese coastal waters. Syst. Biodivers. 7, 235-242.

Gentekaki, E., Kolisko, M., Boscaro, V., Bright, K.J., Dini, F., Di Giuseppe, G., Gong, Y., Miceli, C., Modeo, L., Molestina, R.E., Petroni, G., Pucciarelli, S., Roger, A.J., Strom, S.L., Lynn, D.H., 2014. Large-scale phylogenomic analysis reveals the phylogenetic position of the problematic taxon Protocruzia and unravels the deep phylogenetic affinities of the ciliate lineages. Mol. Phylogenet. Evol. 78, 36-42.

Gentekaki, E., Kolisko, M., Gong, Y., Lynn, D.H., 2017. Phylogenomics solves a long-standing evolutionary puzzle in the ciliate world: the subclass Peritrichia is monophyletic. Mol. Phylogenet. Evol. 106, 1-5.

Gong, Y., Xu, K., Zhan, Z., Yu, Y., Li, X., Villalobo, E., Feng, W., 2010. Alpha-tubulin and small subunit rRNA phylogenies of peritrichs are congruent and do not support the clustering of mobilids and sessilids (Ciliophora, Oligohymenophorea). J. Eukaryot. Microbiol. 57, 265-272.

Hausmann, K., Bradbury, P.C., 1996. Ciliates: Cells as Organisms. Gustav Fischer Verlag.

Hebert, P.D.N., Cywinska, A., Ball, S.L., 2003. Biological identifications through DNA barcodes. Proc. R. Soc. Lond. B Biol. 270, 313-321.

Hu, X., 2008. Cortical structure in non-dividing and dividing Diophrys japanica spec. nov. (Ciliophora: Euplotida) with notes on morphological variation. Eur. J. Protistol. 44, 115-129.

Hu, X.Y., Hu, X., A.L-Rasheid, K.A.S., Al-Farraj, S.A., Song, W.B., 2011. Insights into the phylogeny of sporadotrichid ciliates (Protozoa, Ciliophora: Hypotricha) based on genealogical analyses of multiple molecular markers. Chin. J. Oceanol. Limnol. 29, 96-102.

Hu, X., Song, W.B., 2001. Morphology and morphogenesis of Holosticha heterofoissneri nov. spec. from the Yellow Sea China (Ciliophora, Hypotrichida). Hydrobiologia 448, 171-179.

Hu, X., Song, W.B., Warren, A., 2002. Observations on the morphology and morphogenesis of a new marine urostylid ciliate Parabirojimia similis nov. gen., nov. spec. (Protozoa, Ciliophora, Hypotrichida). Eur. J. Protistol. 38, 351-364.

Huang, J., Chen, Z., Song, W.B., Berger, H., 2014. Three-gene based phylogeny of the Urostyloidea (Protista, Ciliophora, Hypotricha), with notes on classification of some core taxa. Mol. Phylogenet. Evol. 70, 337-347.

Huang, J., Dunthorn, M., Song, W., 2012. Expanding character sampling for the molecular phylogeny of euplotid ciliates (Protozoa, Ciliophora) using three markers, with a focus on the family Uronychiidae. Mol. Phylogenet. Evol. 63, 598-605.

Huang, J., Luo, X., Bourland, W.A., Gao, F., Gao, S., 2016. Multigene-based phylogeny of the ciliate families Amphisiellidae and Trachelostylidae (Protozoa: Ciliophora: Hypotrichia). Mol. Phylogenet. Evol. 101, 101-110.
Jankowski, A.W., 1978. Systematic revision of the class Polyhemenophora (Spirotricha), morphology, systematics and evolution. Zool. Inst. Leningrad. Akad. Nauk. SSSR, 39-40 (in Russian).

Ji, D., Song, W.B., Al-Rasheid, K.A.S., Li, L., 2005. Taxonomic characterization of two new marine peritrichous ciliates, Pseudovorticella clampi n. sp. and Zoothamnium pararbuscula $\mathrm{n}$. sp. (Protozoa: Ciliophora: Peritrichida) from North China. J. Eukaryot. Microbiol. 52, 159-169.

Jiang, J., Song, W.B., 2010. Two new Diophrys-like genera and their type species, Apodiophrys ovalis n. gen., n. sp. and Heterodiophrys zhui n. gen., n. sp. (Ciliophora Euplotida), with notes on their molecular phylogeny. J. Eukaryot. Microbiol. 57, 354-361.

Jiang, J., Zhang, Q., Hu, X., Shao, C., Al-Rasheid, K.A.S., Song, W.B., 2010. Two new marine ciliates, Euplotes sinicus sp. nov. and Euplotes parabalteatus sp. nov. and a new small subunit rRNA gene sequence of Euplotes rariseta (Ciliophora, Spirotrichea, Euplotida). Int. J. Syst. Evol. Microbiol. 60, 1241-1251.

Jiang, J., Warren, A., Song, W.B., 2011. Morphology and molecular phylogeny of two new marine euplotids, Pseudodiophrys nigricans n. g., n. sp. and Paradiophrys zhangi n. sp. (Ciliophora: Euplotida). J. Eukaryot. Microbiol. 58, 437-445.

Kher, C.P., Doerder, F.P., Cooper, J., Ikonomi, P., Achilles-Day, U., Küpper, F.C., Lynn, D.H., 2011. Barcoding Tetrahymena: discriminating species and identifying unknowns using the cytochrome $c$ oxidase subunit I (cox-1) barcode. Protist 162, 2-13.

Li, L., Ma, H., Al-Rasheid, K.A.S., 2015. Monophyly or polyphyly? Further consideration of the well-known peritrichous genus Zoothamnium (Protozoa, Ciliophora): possible conflict between morphological and molecular interpretations. Chin. J. Oceanol. Limnol. 33, 490-499.

Li, L., Shao, C., Song, W.B., Lynn, D.H., Chen, Z., Shin, M.K., 2009a. Is Kiitricha (Ciliophora, Spirotrichea) a member of euplotids or does it represent a low branch of spirotrichs? Int. J. Syst. Evol. Microbiol. 59, 439-446.

Li, L., Song, W.B., Warren, A., Wang, Y., Ma, H., Hu, X., Chen, Z., 2006. Phylogenetic position of the marine ciliate, Cardiostomatella vermiforme (Kahl, 1928) Corliss, 1960 inferred from the complete SSrRNA gene sequence, with establishment of a new order Loxocephalida n. ord. (Ciliophora, Oligohymenophorea). Eur. J. Protistol. 42, 107-114.

Li, Z., Yi, Z., Yang, J., Gong, J., Clamp, J.C., Al-Rasheid, K.A.S., Al-Arifi, S., Al-Khedhairy, A.A., Song, W.B., 2009b. Phylogenetic investigation on five genera of tintinnid ciliates (Ciliophora, Choreotrichia), based on the small subunit ribosomal RNA gene sequences. Prog. Nat. Sci. 19, 1097-1101.

Liu, M., Fan, Y., Miao, M., Hu, X., Al-Rasheid, K.A.S., AlFarraj, S.A., Ma, H., 2015a. Morphological and morphogenetic redescriptions and SSU rRNA gene-based phylogeny of the poorly-known species Euplotes amieti Dragesco, 1970 (Ciliophora, Euplotida). Acta Protozool. 54, 173-184.

Liu, M., Gao, F., Al-Farraj, S.A., Hu, X.Z., 2016. Morphology and small subunit rRNA gene sequence of Uronemita parabinucleata n. sp. (Ciliophora, Uronematidae), with an improved generic diagnosis and the key to species of Uronemita. Eur. J. Protistol. $54,1-10$.

Liu, W., Yi, Z., Lin, X., Al-Rasheid, K.A.S., 2011. Morphologic and molecular data suggest that Lynnella semiglobulosa n. g., 
n. sp. represents a new family within the subclass Choreotrichia (Ciliophora, Spirotrichea). J. Eukaryot. Microbiol. 58, 43-49.

Liu, W., Yi, Z., Xu, D., Clamp, J.C., Li, J., Lin, X., Song, W.B., 2015b. Two new genera of planktonic ciliates and insights into the evolution of the family Strombidiidae (Protista, Ciliophora, Oligotrichia). PLoS One 10, e0131726.

Liu, W., Yi, Z., Lin, X., Li, J., Al-Farraj, S.A., Al-Rasheid, K.A.S., Song, W.B., 2015c. Morphology and molecular phylogeny of three new oligotrich ciliates (Protozoa, Ciliophora) from the South China Sea. Zool. J. Linn. Soc. 174, 653-665.

Lobban, C.S., Modeo, L., Verni, F., Rosati, G., 2005. Euplotes uncinatus (Ciliophora, Hypotrichia), a new species with zooxanthellae. Mar. Biol. 147, 1055-1061.

Luo, X., Gao, F., Al-Rasheid, K.A.S., Warren, A., Hu, X., Song, W.B., 2015. Redefinition of the hypotrichous ciliate Uncinata, with descriptions of the morphology and phylogeny of three urostylids (Protista, Ciliophora). Syst. Biodivers. 13, 455-471.

Luo, X., Hu, X., Suzuki, T., 2014. Microscopic investigation of three species of Diophrys (Ciliophora Euplotida, Uronychiidae) from Japan, including Diophrys peculiaris nov. spec. Eur. J. Prositol. 50, 496-508.

Lv, Z., Shao, C., Yi, Z., Warren, A., 2015. A molecular phylogenetic investigation of Bakuella, Anteholosticha, and Caudiholosticha (Protista, Ciliophora, Hypotrichia) based on three-gene sequences. J. Eukaryot. Microbiol. 62, 391-399.

Lynn, D.H., Strüder-Kypke, M., 2005. Scuticociliate endosymbionts of echinoids (phylum Echinodermata): phylogenetic relationships among species in the genera Entodiscus, Plagiopyliella, Thyrophylax, and Entorhipidium (phylum Ciliophora). J. Parasitol. 91, 1190-1199.

Lynn, D.H., 2008. The Ciliated Protozoa: Characterization, Classification and Guide to the Literature, 3rd ed. Springer, Dordrecht.

McManus, G.B., Katz, L.A., 2009. Molecular and morphological methods for identifying plankton: what makes a successful marriage? J. Plankton. Res. 31, 1119-1129.

Miao, M., Shao, C., Chen, X., Song, W.B., 2011. Evolution of discocephalid ciliates: molecular, morphological and ontogenetic data support a sister group of discocephalids and pseudoamphisiellids (Protozoa, Ciliophora) with establishment of a new suborder Pseudoamphisiellina subord. n. Sci. China (Life Sci.) 54, 634-641.

Miao, M., Song, W.B., Chen, Z., Al-Rasheid, K.A.S., Shao, C., Jiang, J., Guo, W., 2007. A unique euplotid ciliate, Gastrocirrhus (Protozoa, Ciliophora): with assessment of its phylogenetic position inferred from the small subunit rRNA gene sequence. J. Eukaryot. Microbiol. 54, 371-378.

Miao, M., Wang, Y., Song, W.B., Clamp, J.C., Al-Rasheid, K.A.S., 2010. Description of Eurystomatella sinica n. gen. n. sp., with establishment of a new family Eurystomatellidae n. fam. (Protista, Ciliophora, Scuticociliatia) and analyses of its phylogeny inferred from sequences of the small-subunit rRNA gene. Int. J. Syst. Evol. Microbiol. 60, 460-468.

Pan, H., Hu, J., Jiang, J., Wang, L., Hu, X., 2016. Morphology and phylogeny of three Pleuronema species (Ciliophora Scuticociliatia) from Hangzhou Bay, China, with description of two new species, $P$. binucleatum n. sp. and $P$. parawiackowskii n. sp. J. Eukaryot. Microbiol. 63, 287-298.

Pan, X., Yi, Z., Li, J., Ma, H., Al-Farraj, S.A., Al-Rasheid, K.A.S., 2015. Biodiversity of marine scuticociliates (Protozoa, Ciliophora) from China: description of seven morphotypes including a new species, Philaster sinensis spec. nov. Eur. J. Protistol. 51, $142-157$.

Pan, X., Zhu, M., Ma, H., Al-Rasheid, K.A.S., Hu, X., 2013. Morphology and small-subunit rRNA gene sequences of two novel marine ciliates, Metanophrys orientalis spec. nov. and Uronemella sinensis spec. nov. (Protista, Ciliophora, Scuticociliatia), with an improved diagnosis of the genus Uronemella. Int. J. Syst. Evol. Microbiol. 63, 3515-3523.

Pawlowski, J., Audic, S., Adl, S., Bass, D., Belbahri, L., Berney, C., Bowser, S.S., Cepicka, I., Decelle, J., Dunthorn, M., FioreDonno, A.M., Gile, G.H., Holzmann, M., Jahn, R., Jirku, M., Keeling, P.J., Kostka, M., Kudryavtsev, A., Lara, E., Lukeš, J., Mann, D.G., Mitchell, E.A.D., Nitsche, F., Romeralo, M., Saunders, G.W., Simpson, A.G.B., Smirnov, A.V., Spouge, J.L., Stern, R.F., Stoeck, T., Zimmermann, J., Schindel, D., de Vargas, C., 2012. CBOL protist working group: barcoding eukaryotic richness beyond the animal, plant, and fungal kingdoms. PLoS Biol. 10, e1001419.

Pierce, R.W., Turner, J.T., 1992. Ecology of planktonic ciliates in marine food webs. Rev. Aquat. Sci. 6, 139-181.

Santoferrara, L.F., Bachy, C., Alder, V.A., Gong, J., Kim, Y.O., Saccà, A., Silva, I.D., Strüder-Kypke, M.C., Warren, A., Xu, D., Yi, Z., Agatha, S., 2016. Updating biodiversity studies in loricate protists: the case of the tintinnids (Alveolata, Ciliophora, Spirotrichea). J. Eukaryot. Microbiol. 63, 651-656.

Schmidt, S.L., Bernhard, D., Schlegel, M., Foissner, W., 2007. Phylogeny of the Stichotrichia (Ciliophora; Spirotrichea) reconstructed with nuclear small subunit rRNA gene sequences: discrepancies and accordances with morphological data. J. Eukaryot. Microbiol. 54, 201-209.

Shen, Z., Ji, D., Yi, Z., Al-Rasheid, K.A.S., Lin, X., 2017. Morphology and phylogenetic placement of three new Zoothamnium species (Ciliophora: Peritrichia) from coastal waters of southern China. J. Eukaryot. Microbiol. 64, 266-277.

Shen, Z., Shao, C., Gao, S., Lin, X., Li, J., Hu, X., Song, W.B., 2009. Description of the rare marine ciliate, Uronychia multicirrus Song, 1997 (Ciliophora; Euplotida) based on morphology, morphogenesis and SS rRNA gene sequence. J. Eukaryot. Microbiol. 56, 296-304.

Song, W., Li, J., Liu, W., Al-Rasheid, K.A.S., Hu, X., Lin, X., 2015a. Taxonomy and molecular phylogeny of four Strombidium species including description of S. pseudostylifer sp. nov. (Ciliophora, Oligotrichia). Syst. Biodivers. 13, 76-92.

Song, W.B., Warren, A., Hu, X., 2009. Free-Living Ciliates in the Bohai and Yellow Seas, China. Science Press, Beijing.

Song, W.B., Wilbert, N., Chen, Z., Shi, X., 2004. Considerations on the systematic position of Uronychia and related euplotids based on the data of ontogeny and $18 \mathrm{~S}$ rRNA gene sequence analyses, with morphogenetic redescription of Uronychia setigera Calkins, 1902 (Ciliophora, Euplotida). Acta Protozool. 43, 313-328.

Song, W., Zhao, X., Liu, W., Hu, X., Al-Farraj, S.A., Al-Rasheid, K.A.S., Song, W.B., Warren, A., 2015b. Biodiversity of oligotrich ciliates in the South China Sea: description of three new Strombidium species (Protozoa, Ciliophora, Oligotrichia) with phylogenetic analyses. Syst. Biodivers. 13, 608-623.

Song, W.B., Zhao, Y., Xu, K., Hu, X., Gong, J., 2003. Pathogenic Protozoa in Mariculture. Science Press, Beijing.

Strüder-Kypke, M.C., Lynn, D.H., 2010. Comparative analysis of the mitochondrial cytochrome c oxidase subunit I (COI) gene in 
ciliates (Alveolata, Ciliophora) and evaluation of its suitability as a biodiversity marker. Syst. Biodivers. 8, 131-148.

Wang, P., Gao, F., Huang, J., Strüder-Kypke, M., Yi, Z., 2015. A case study to estimate the applicability of secondary structures of SSU-rRNA gene in taxonomy and phylogenetic analyses of ciliates. Zool. Scr. 44, 574-585.

Xu, Y., Pan, H., Miao, M., Hu, X., Al-Rasheid, K.A.S., Song, W.B., 2015. Morphology and phylogeny of two species of Loxodes (Ciliophora Karyorelictea), with description of a new subspecies, Loxodes striatus orientalis subsp. n. J. Eukaryot. Microbiol. 62, 206-216.

Yan, Y., Chen, X.M., Chen, X.R., Gao, F., Al-Farraj, S.A., AlRasheid, K.A.S., 2015. Morphology and molecular phylogeny of three marine Condylostoma species from China, including two new ones (Ciliophora, Heterotrichea). Eur. J. Protistol. 51, $66-78$.

Yan, Y., Fan, Y., Chen, X., Li, L., Warren, A., Al-Farraj, S.A., Song, W.B., 2016a. Taxonomy and phylogeny of three heterotrich ciliates (Protozoa Ciliophora), with description of a new Blepharisma species. Zool. J. Linn. Soc. 177, 320-334.

Yan, Y., Xu, Y., Al-Farraj, S.A., Al-Rasheid, K.A.S., Song, W.B., 2016b. Morphology and phylogeny of three trachelocercids (Protozoa Ciliophora, Karyorelictea), with description of two new species and insight to the evolution of the family Trachelocercidae. Zool. J. Linn. Soc. 177, 306-319.

Yi, Z., Dunthorn, M., Song, W.B., Stoeck, T., 2010. Increasing taxon sampling using both unidentified environmental sequences and identified cultures improves phylogenetic inference in the Prorodontida (Ciliophora, Prostomatea). Mol. Phylogenet. Evol. 57, 937-941

Yi, Z., Miao, M., Gao, S., Gao, F., Song, W.B., 2016. On molecular biology of ciliated protozoa: frontier areas and progresses (in Chinese). Chin. Sci. Bull. 61, 2227-2238 (in Chinese with English Abstract)

Yi, Z., Song, W.B., Clamp, J.C., Chen, Z., Gao, S., Zhang, Q., 2009. Reconsideration of systematic relationships within the order Euplotida (Protista, Ciliophora) using new sequences of the gene coding for small-subunit rRNA and testing the use of combined data sets to construct phylogenies of the Diophrys-complex. Mol. Phylogenet. Evol. 50, 599-607.

Yi, Z., Song, W.B., Warren, A., Roberts, D.M., Al-Rasheid, K.A.S., Chen, Z., Al-Farraj, S.A., Hu, X., 2008. A molecular phylogenetic investigation of Pseudoamphisiella and Parabirojimia (Protozoa Ciliophora, Spirotrichea), two genera with ambiguous systematic positions. Eur. J. Protistol. 44, 45-53.

Yi, Z., Song, W.B., 2011. Evolution of the order Urostylida (Protozoa, Ciliophora): new hypotheses based on multi-gene information and identification of localized incongruence. PLoS One 6, e17471.
Yi, Z., Strüder-Kypke, M.C., Hu, X., Lin, X., Song, W.B., 2014. Sampling strategies for improving tree accuracy and phylogenetic analyses: a case study in ciliate protists, with notes on the genus Paramecium. Mol. Phylogenet. Evol. 71, 142-148.

Zhan, Z., Xu, K., Dunthorn, M., 2013. Evaluating molecular support for and against the monophyly of the Peritrichia and phylogenetic relationships within the Mobilida (Ciliophora, Oligohymenophorea). Zool. Scr. 42, 213-226.

Zhan, Z., Xu, K., Warren, A., Gong, Y., 2009. Reconsideration of phylogenetic relationships of the subclass Peritrichia (Ciliophora, Oligohymenophorea) based on small subunit ribosomal RNA gene sequences, with the establishment of a new subclass Mobilia Kahl, 1933. J. Eukaryot. Microbiol. 56, 552-558.

Zhang, Q., Fan, X., Clamp, J.C., Al-Rasheid, K.A.S., Song, W.B., 2010. Description of Paratetrahymena parawassi n. sp. using morphological and molecular evidence and a phylogenetic analysis of Paratetrahymena and other taxonomically ambiguous genera in the order Loxocephalida (Ciliophora, Oligohymenophorea). J. Eukaryot. Microbiol. 57, 483-493.

Zhang, Q., Miao, M., Strüder-Kypke, M., Al-Rasheid, K.A.S., Al-Farrah, S., Song, W.B., 2011. Molecular evolution of Cinetochilum and Sathrophilus (Protozoa Ciliophora, Oligohymenophorea), two genera of ciliates with morphological affinities to scuticociliates. Zool. Scr. 40, 317-325.

Zhang, Q., Simpson, A., Song, W.B., 2012. Insights into the phylogeny of systematically controversial haptorian ciliates (Ciliophora, Litostomatea) based on multigene analyses. Proc. R. Soc. B 279, 2625-2635.

Zhang, Q., Yi, Z., Fan, X., Warren, A., Gong, J., Song, W.B., 2014. Further insights into the phylogeny of two ciliate classes Nassophorea and Prostomatea (Protista, Ciliophora). Mol. Phylogenet. Evol. 70, 162-170.

Zhao, X., Gao, S., Fan, Y., Strüder-Kypke, M., Huang, J., 2015. Phylogenetic framework of the systematically confused Anteholosticha-Holosticha complex (Ciliophora, Hypotrichia) based on multigene analysis. Mol. Phylogenet. Evol. 91, $238-247$.

Zhao, X., Miao, M., Chen, X.R., Ma, H., Al-Rasheid, K.A.S., 2014. A phylogenetic reconsideration of suctorian ciliates (Protista, Ciliophora, Phyllopharyngea) based on small subunit rRNA gene sequences. Zool. Scr. 43, 206-216.

Zhao, Y., Gentekaki, E., Yi, Z., Lin, X., 2013. Genetic differentiation of the mitochondrial cytochrome oxidase $c$ subunit I gene in genus Paramecium (Protista, Ciliophora). PLoS One 8, e77044.

Zhao, Y., Yi, Z., Gentekaki, E., Zhan, A., Al-Farraj, S.A., Song, W.B., 2016. Utility of combining morphological characters, nuclear and mitochondrial genes: an attempt to resolve the conflicts of species identification for ciliated protists. Mol. Phylogenet. Evol. 94, 718-729. 